\title{
CAUSES OF RAPTOR ADMISSIONS TO A WILDLIFE REHABILITATION CENTER IN TENERIFE (CANARY ISLANDS)
}

\author{
BENEHARO RODRÍGUEZ ${ }^{1}$ \\ La Malecita s/n, E-38480 Buenavista del Norte, Tenerife, Canary Islands, Spain
}

AIRAM RoDRÍGUEZ
Department of Evolutionary Ecology, Estación Biológica de Doñana (CSIC), Avda. Américo Vespucio s/n,
E-41092 Seville, Spain

FELIPE Siverio

Los Barros 21, E-38410 Los Realejos, Tenerife, Canary Islands, Spain

\author{
MANUEL SIVERIO \\ Constitución 19-3, E-38410 Los Realejos, Tenerife, Canary Islands, Spain
}

\begin{abstract}
We studied the causes of raptor admissions to the only wildlife rehabilitation center on the largest island of the Canarian Archipelago (Tenerife) over ten years (1998-2007). A total of 2611 birds of prey, belonging to nine falconiform diurnal raptor and four strigiform species, were admitted. The Eurasian Kestrel (Falco tinnunculus) and the Long-eared Owl (Asio otus) were the species most commonly admitted and jointly made up $85.6 \%$ of admissions. The most frequent causes of admission to the wildlife rehabilitation center were collisions (with cars, high-voltage electric transmission towers, etc.; 42.2\%), starvation $(5.1 \%)$ and entanglement in glue traps intended for rodents $(4.7 \%)$. Poisoning and shooting were recorded for 2.4 and $1.5 \%$ of the birds admitted, respectively. Only collisions increased during the study period. A total of 1010 birds $(44.4 \%$ of the total) were released to the wild following rehabilitation. We recommend more financial support for rehabilitation centers to develop detailed analytical diagnoses and rehabilitation services.
\end{abstract}

KeY Words: Eurasian Kestrel; Falco tinnunculus; Long-eared Owl; Asio otus; Canary Islands; conservation; mortality; raptor, wildlife rehabilitation center.

\section{CAUSAS DE ADMISIÓN DE AVES RAPACES A UN CENTRO DE RECUPERACIÓN EN TENERIFE, ISLAS CANARIAS}

RESUMEN.-Estudiamos las causas de ingreso de rapaces al único centro de recuperación de fauna silvestre de Tenerife, la isla con mayor superficie del archipiélago canario, durante diez años (1998-2007). Un total de 2.611 aves de presa, pertenecientes a nueve especies de Falconiformes y a cuatro de Strigiformes, fueron ingresadas. Las especies Falco tinnunculus y Asio otus constituyeron las especies más asiduas, sumando el 85.6\% del total de ingresos. Las causas más frecuentes de ingreso al centro de recuperación de fauna silvestre fueron las colisiones (con coches, líneas eléctricas, etc., $42.2 \%$ ), la inanición (5.1\%) y la adherencia al pegamento usado en las trampas para roedores $(4.7 \%)$. El envenenamiento y las heridas por disparos se registraron en el 2.4 y el $1.5 \%$ de los casos, respectivamente. De todas las causas de ingreso, sólo las colisiones aumentaron durante el periodo estudiado. Un total de 1.010 aves (44.4\% de todas las ingresadas) fueron liberadas después de su rehabilitación. Recomendamos aumentar el presupuesto de los centros de recuperación, lo que resultaría en diagnósticos analíticos más precisos y mejores servicios de rehabilitación.

[Traducción del equipo editorial]

\footnotetext{
${ }^{1}$ Email address: benerguez@terra.es
} 
Table 1. Distribution, estimated numbers (taken from Lorenzo 2007), and IUCN threat category (Madroño et al. 2004) of the breeding raptors of the Canary Islands $(\mathrm{L}=$ Lanzarote including the northern islets, $\mathrm{F}=$ Fuerteventura, Gc $=$ Gran Canaria, $\mathrm{T}=$ Tenerife, $\mathrm{P}=\mathrm{La}$ Palma, $\mathrm{G}=\mathrm{La}$ Gomera, $\mathrm{H}=$ El Hierro, Ce $=$ Canarian endemism, Me = Macaronesian endemism, $\mathrm{CE}=$ Critically Endangered, EN $=$ Endangered, $\mathrm{VU}=$ Vulnerable, $\mathrm{NT}=$ Near Threatened).

\begin{tabular}{|c|c|c|c|c|c|}
\hline \multirow[b]{2}{*}{ SPECIES } & \multirow[b]{2}{*}{$\begin{array}{c}\text { ISLAND } \\
\text { DISTRIBUTION }\end{array}$} & \multirow[b]{2}{*}{$\begin{array}{c}\text { BIOGEOGRAPHICAL } \\
\text { RANGE }\end{array}$} & \multirow[b]{2}{*}{$\begin{array}{c}\text { IUCN } \\
\text { CATEGORY }\end{array}$} & \multicolumn{2}{|c|}{ Breeding Pairs in } \\
\hline & & & & $\begin{array}{l}\text { CANARY } \\
\text { ISLANDS }\end{array}$ & TENERIFE \\
\hline Egyptian Vulture (Neophron percnopterus majorensis) & $\mathrm{L}, \mathrm{F}$ & $\mathrm{Ce}$ & $\mathrm{CE}$ & 25 & Extirpated \\
\hline Eurasian Sparrowhawk (Accipiter nisus granti) & $\mathrm{Gc}, \mathrm{T}, \mathrm{P}, \mathrm{G}, \mathrm{H}$ & $\mathrm{Me}$ & VU & 150 & 75 \\
\hline Eurasian Buzzard (Buteo buteo insularum) & All except $\mathrm{L}$ & $\mathrm{Ce}$ & NT & $430-445$ & $170-180$ \\
\hline Osprey (Pandion haliaetus) & $\mathrm{L}, \mathrm{T}, \mathrm{G}, \mathrm{H}$ & - & $\mathrm{CE}$ & 18 & $4-5$ \\
\hline Eurasian Kestrel (Falco tinnunculus canariensis) & $\mathrm{Gc}, \mathrm{T}, \mathrm{P}, \mathrm{G}, \mathrm{H}$ & $\mathrm{Me}$ & - & $7110-8820$ & $1100-1300$ \\
\hline Eurasian Kestrel (Falco tinnunculus dacotiae) & $\mathrm{L}, \mathrm{F}$ & $\mathrm{Ce}$ & VU & $286-387$ & - \\
\hline Eleonora's Falcon (Falco eleonorae) & $\mathrm{L}$ & - & NT & 200 & - \\
\hline Barbary Falcon (Falco peregrinus pelegrinoides) & All & - & EN & $85-116$ & 26 \\
\hline Barn Owl (Tyto alba) & $\mathrm{Gc}, \mathrm{T}, \mathrm{P}, \mathrm{G}, \mathrm{H}$ & - & - & $400-500$ & 150 \\
\hline Barn Owl (Tyto alba gracilirostris) & $\mathrm{L}, \mathrm{F}$ & $\mathrm{Ce}$ & EN & $80-105$ & - \\
\hline Long-eared Owl (Asio otus canariensis) & All except L & $\mathrm{Ce}$ & - & $>2000$ & ? \\
\hline
\end{tabular}

Anthropogenic causes of avian mortality include poisoning, collisions (road traffic, power lines, etc.), commercial fishing, predation by introduced species, and hunting (Harden 2002). In raptors, environmental contaminants (Pain and Amiard-Triquet 1993, López et al. 2001, Hernández and Margalida 2008), powerline collisions (Bevanger 1998) and direct human persecution (Elliot and Avery 1991, Margalida et al. 2008) may also be factors affecting population dynamics. Detailed knowledge of the spatial and temporal variation of mortality causes may be useful for developing effective conservation measures, as they are an essential component of demographic studies (Cooper 2004, González et al. 2007).

Due to their particular life-history traits, insular bird populations are usually more vulnerable to extirpation than their mainland relatives (Duncan and Blackburn 2007), especially on islands where habitats have been greatly altered by humans. Raptors living on islands with high densities of human population may be more likely to be extirpated (Donázar et al. 2005). This is the case in the Canarian archipelago, an area in which some vulnerable species, such as some seabirds, steppe birds, and large raptors, are seriously threatened (Madroño et al. 2004). As urban development and human populations are gradually increasing, threats for these species are still growing.

Near the end of the twentieth century, the Red Kite (Milvus milvus) disappeared from the Canary Islands, while the Egyptian Vulture (Neophron perc- nopterus majorensis) was extirpated from several islands (Martín and Lorenzo 2001), apparently due to human-induced causes (Donázar et al. 2002). Currently, nine raptor species (including two owls) breed in this archipelago; some are endemic subspecies and/or endangered or threatened (Madroño et al. 2004, Table 1). Furthermore, at least 33 migratory raptor species have been sighted in the Canaries (Martín and Lorenzo 2001). However, few quantitative data have been published on the direct and indirect causes of mortality of local breeding species (see Carrillo and Delgado 1991, Donázar et al. 2002, Madroño et al. 2004, Palacios 2004, Gangoso et al. 2009), and almost nothing on the subject for migrants.

The purpose of our study was to examine the primary causes of human-caused mortality for raptor species (both resident and migratory) on the largest of the Canary Islands (Tenerife), using information on admissions to a wildlife rehabilitation center as an index to causes of mortality.

\section{METHODS}

Study Area. The Canary Islands comprise a volcanic archipelago located $100 \mathrm{~km}$ off the Atlantic coast of northwest Africa $\left(27^{\circ} 37^{\prime}-29^{\circ} 25^{\prime} \mathrm{N}\right.$ and $13^{\circ} 20^{\prime}-18^{\circ} 19^{\prime} \mathrm{W}$ ) and include seven major islands with some small islets and rocks. The study was conducted on Tenerife, which is the largest island (2034 $\mathrm{km}^{2}$ and $3718 \mathrm{~m}$ asl at its highest point), and is located in the central part of the archipelago. 
Although about $48.6 \%$ of the land is protected under the local nature protection laws, urbanization and the construction of infrastructure have increased considerably during the last $40 \mathrm{yr}$, and such areas now cover more than $5.7 \%$ of total land surface (Cabildo Insular de Tenerife 2009). Since 1996, human population has increased $30 \%$ annually, reaching more than 865000 inhabitants in 2007 (mean density 425.3 inhabitant $/ \mathrm{km}^{2}$ ), the majority of whom live along the coast (Morales and Pérez 2000, National Statistic Institute of Spain 2009). Of all the raptors that breed in the Canarian archipelago (Table 1), on Tenerife only the Egyptian Vulture (recently extirpated) and Eleonora's Falcon (Falco eleonorae) are absent. The Canarian raptor community is completed by migratory species, some of them regularly sighted and others considered vagrant (Martín and Lorenzo 2001).

Recovery of Injured Birds. A recovery program for injured wildlife species at the Wildlife Rehabilitation Center "La Tahonilla" (hereafter WRC) is managed by the "Cabildo Insular de Tenerife." The public, local authorities, and different organizations report injured wildlife to the WRC, and animals (all from the island of Tenerife) are collected by its staff, identified, and examined. Injured birds are held for rehabilitation or euthanized; rehabilitated birds are banded and released back to the wild. Whenever possible, locality, date, age class, and date and location of release are recorded for each bird. Here, we report on data from raptor admissions during the period 1998-2007. Reasons for admission were classified in nine categories: (1) shooting, (2) collision, (3) disease, (4) poisoning, (5) glue-trapping, (6) starvation, (7) poaching, (8) other, and (9) unknown. In general, to assign these categories we used (1) direct evidence obtained by inspection of the location where the bird was found, (2) information from the people that recovered the bird and (3) other diagnostic symptoms. For example, to detect shooting, open wounds were inspected for shot or, in some cases (e.g., for rare or threatened species), X-rays were taken. In the collision category we included all the birds admitted as a result of collisions with fences, power lines, wind turbines, or vehicles, and also all the birds presenting fractures or broken limbs of unknown origin. Diseased birds were those presenting parasites or lesions in vital organs, and many of them were emaciated. Poisoned birds were identified using external symptoms (incapacity to fly, dribble of fluids from the bill or cloacae, stiffness of neck, dilated pupil and gut damage). Birds with low weight, wasted muscles (especially in the breast) and without body fat, and without other symptoms of the previous categories, were classified as starving. Some Long-eared Owls (Asio otus), Barn Owls (Tyto alba) and Eurasian Kestrels (Falco tinnunculus) were admitted with plumage damage or inability to fly due to entanglement in the plant burr bristlegrass (Setaria adhaerens; see Rodríguez et al. 2009), and were included in the (8) other category. A small fraction of the birds officially admitted to the WRC were already dead when collected by WRC staff or died before arrival at the WRC, but were recorded as admitted nonetheless; these birds were included in our study. Individuals of captive origin (e.g., falconry birds) were excluded from our analysis. For the purpose of this study, we assumed that all admitted birds would have died had they not been reported to WCR, although this assumption could not be tested and likely was not entirely correct.

Population Size. To examine the relationship between admission rate for various species and local population sizes for those species, we used population data from 1997-2003 from the recently published Atlas of Breeding Birds of the Canarian Archipelago (Lorenzo 2007, see Table 1).

Data Analysis. We used $G$ - tests to evaluate differences among years in the number of individuals of each species, and in the frequency distributions of the causes of mortality. Pearson and Spearman rank correlations were used to evaluate the relationship between population size and the number of admitted birds of each species, and to investigate the variation in the number of birds admitted annually during the study period. Because injured birds were more prone to be found in populated areas and the precise location of the injured bird was usually unknown, we did not attempt any spatial analysis. Statistical analyses were conducted using SPSS v.15.

\section{RESUlTS}

Numbers and Species of Raptors Admitted. A total of 2611 raptors, belonging to nine diurnal raptor and four owl species, were admitted to the WRC during 1998-2007 (Table 2). The majority of individuals (85.6\%) were two resident breeding species, the Eurasian Kestrel and Long-eared Owl, and migratory species were admitted in low numbers (Table 2). We found a positive correlation between estimated population size (Table 1) and the number of injured individuals (variables log-transformed, $r=0.95 ; n=$ $7 ; P=0.001)$. The number of raptors admitted in- 


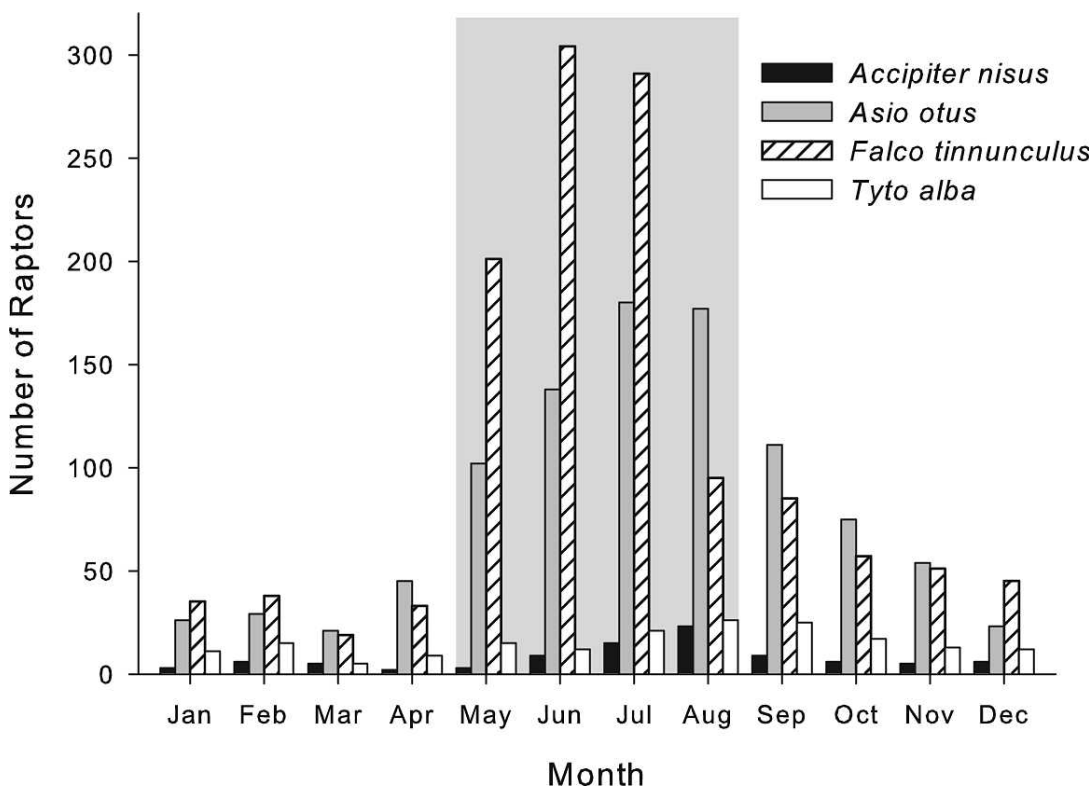

Figure 1. Monthly admissions to the Wildlife Rehabilitation Center "La Tahonilla" (Tenerife, Canary Islands) of the most abundant raptors during 1998-2007. The area shaded gray shows the period of first flight of juveniles for all species (combined according to Martín and Lorenzo 2001).

creased through the years of the study period $\left(r_{\mathrm{s}}=\right.$ $0.89 ; n=10 ; P=0.001$; Table 2). Admissions of the most abundant breeding species peaked during those species' fledging periods (Fig. 1).
Causes of Admission to the Rehabilitation Center. Collisions were the primary cause of admission to the WRC, representing $42.2 \%$ of the total admissions (Table 3). Excluding rare species (fewer than

Table 2. Number of raptors admitted to the Wildlife Rehabilitation Center "La Tahonilla" (Tenerife, Canary Islands) during 1998-2007.

\begin{tabular}{|c|c|c|c|c|c|c|c|c|c|c|c|}
\hline \multirow[b]{2}{*}{ SPECIES } & \multicolumn{11}{|c|}{ YEAR } \\
\hline & 1998 & 1999 & 2000 & 2001 & 2002 & 2003 & 2004 & 2005 & 2006 & 2007 & TOTAL \\
\hline \multicolumn{12}{|l|}{ Residents } \\
\hline Accipiter nisus & 9 & 8 & 8 & 8 & 10 & 13 & 9 & 12 & 5 & 10 & 92 \\
\hline Buteo buteo & 7 & 5 & 8 & 9 & 6 & 6 & 10 & 6 & 5 & 3 & 65 \\
\hline Pandion haliaetus & - & 3 & - & - & 2 & 1 & 1 & 2 & - & - & 9 \\
\hline Falco tinnunculus & 82 & 82 & 110 & 90 & 111 & 127 & 113 & 151 & 204 & 184 & 1254 \\
\hline Falco $p$. pelegrinoides & 1 & - & 1 & - & 1 & 1 & 4 & 3 & 4 & 5 & 20 \\
\hline Tyto alba & 16 & 10 & 19 & 10 & 23 & 30 & 18 & 15 & 21 & 19 & 181 \\
\hline Asio otus & 87 & 62 & 64 & 64 & 79 & 131 & 110 & 146 & 136 & 102 & 981 \\
\hline \multicolumn{12}{|l|}{ Migratory species } \\
\hline Circus macrourus & - & - & - & - & - & - & - & 1 & - & - & 1 \\
\hline Hieraaetus pennatus & - & - & - & - & - & - & - & 1 & - & 1 & 2 \\
\hline Falco vespertinus & - & - & - & - & 1 & - & - & - & - & - & 1 \\
\hline Falco eleonorae & - & - & 1 & - & - & - & - & - & - & - & 1 \\
\hline Otus scops & - & - & - & - & - & - & - & - & 2 & - & 2 \\
\hline Asio flammeus & - & - & - & - & - & - & - & - & - & 2 & 2 \\
\hline Total & 202 & 170 & 211 & 181 & 233 & 309 & 265 & 337 & 377 & 326 & 2611 \\
\hline
\end{tabular}




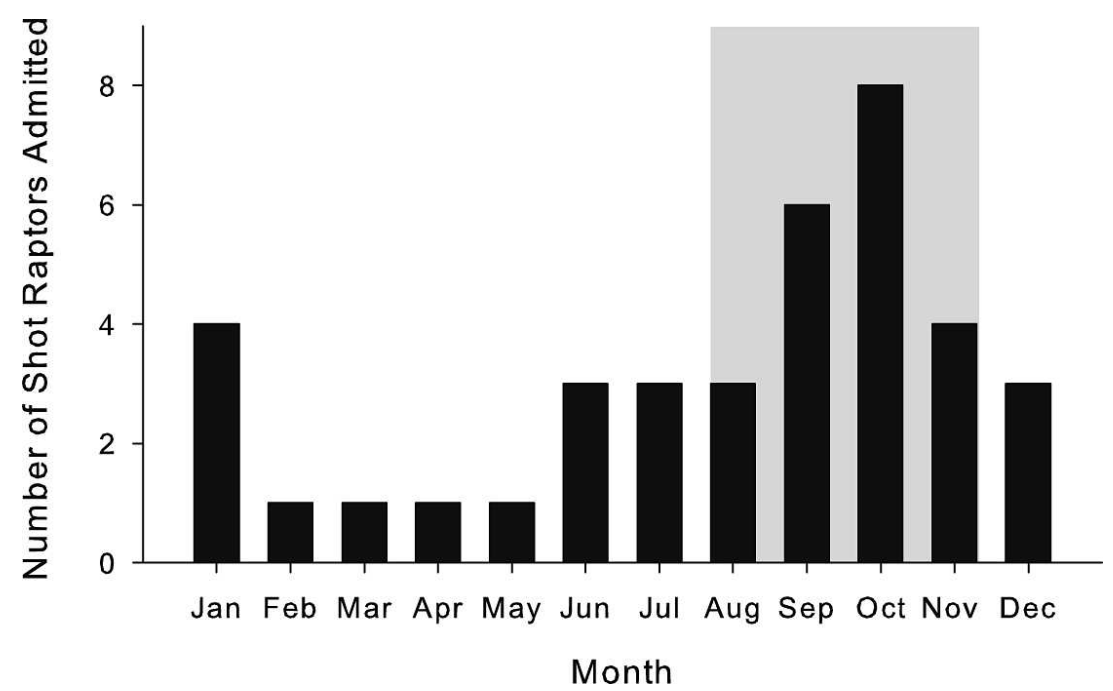

Figure 2. Monthly admissions to the Wildlife Rehabilitation Center "La Tahonilla" (Tenerife, Canary Islands) for raptors that had been shot. The area shaded gray indicates the official hunting season during 1998-2007.

10 individuals), collisions were the most important cause of admission for many species, ranging from $60 \%$ in Barbary Falcon (Falco peregrinus pelegrinoides) to $35.4 \%$ in the Eurasian Buzzard (Buteo buteo; Table 3). Less important causes of mortality were starvation $(5.1 \%)$ and glue-trapping $(4.7 \%)$. Shooting was also a cause of admission for all the breeding species, ranging from $12.3 \%$ in the Eurasian Buzzard to $0.6 \%$ in the Barn Owl. Shot birds were admitted primarily during the hunting season, but also outside of this period (Fig. 2). Poisoning was confirmed in only four common breeding species (Eurasian Buzzard, Eurasian Kestrel, Barn Owl, and Long-eared Owl) but in all cases in low numbers. Migratory species, with only nine admissions, were affected primarily by collisions and starvation (Table 3 ).

Most causes of admission varied significantly among years (all $G$ values $>23.76$, all $P<0.005$,

Table 3. Causes of injury and percentage of raptors released to the wild after being admitted to the Wildlife Rehabilitation Center "La Tahonilla" (Tenerife, Canary Islands) during 1998-2007.

\begin{tabular}{|c|c|c|c|c|c|c|c|c|c|c|}
\hline SPECIES & SHOOTING & Collision & Disease & POISONING & Glue & STARVATION & PoAching & OTHER & UNKNOWN & RELEASED (\%) \\
\hline \multicolumn{11}{|l|}{ Residents } \\
\hline Accipiter nisus & 2 & 51 & 3 & 0 & 2 & 5 & 0 & 2 & 27 & 29.3 \\
\hline Buteo buteo & 8 & 23 & 1 & 9 & 0 & 2 & 2 & 6 & 14 & 52.3 \\
\hline Pandion haliaetus & 1 & 1 & 1 & 0 & 0 & 1 & 0 & 2 & 3 & 33.3 \\
\hline Falco tinnunculus & 18 & 423 & 18 & 47 & 40 & 91 & 29 & 101 & 487 & 38.9 \\
\hline Falco $p$. pelegrinoides & 1 & 12 & 3 & 0 & 0 & 0 & 1 & 0 & 3 & 15.0 \\
\hline Tyto alba & 1 & 113 & 2 & 3 & 9 & 2 & 0 & 16 & 35 & 29.3 \\
\hline Asio otus & 7 & 474 & 9 & 3 & 72 & 28 & 2 & 101 & 285 & 40.5 \\
\hline \multicolumn{11}{|l|}{ Migratory species } \\
\hline Circus macrourus & 0 & 0 & 0 & 0 & 0 & 1 & 0 & 0 & 0 & 100 \\
\hline Hieraaetus pennatus & 0 & 1 & 0 & 0 & 0 & 1 & 0 & 0 & 0 & 0 \\
\hline Falco vespertinus & 0 & 1 & 0 & 0 & 0 & 0 & 0 & 0 & 0 & 100 \\
\hline Falco eleonorae & 0 & 0 & 0 & 0 & 0 & 0 & 0 & 0 & 1 & 100 \\
\hline Otus scops & 0 & 1 & 0 & 0 & 0 & 1 & 0 & 0 & 0 & 50.0 \\
\hline Asio flammeus & 0 & 1 & 0 & 0 & 0 & 0 & 0 & 0 & 1 & 50.0 \\
\hline Total & 38 & 1101 & 37 & 62 & 123 & 132 & 34 & 228 & 856 & 44.4 \\
\hline
\end{tabular}




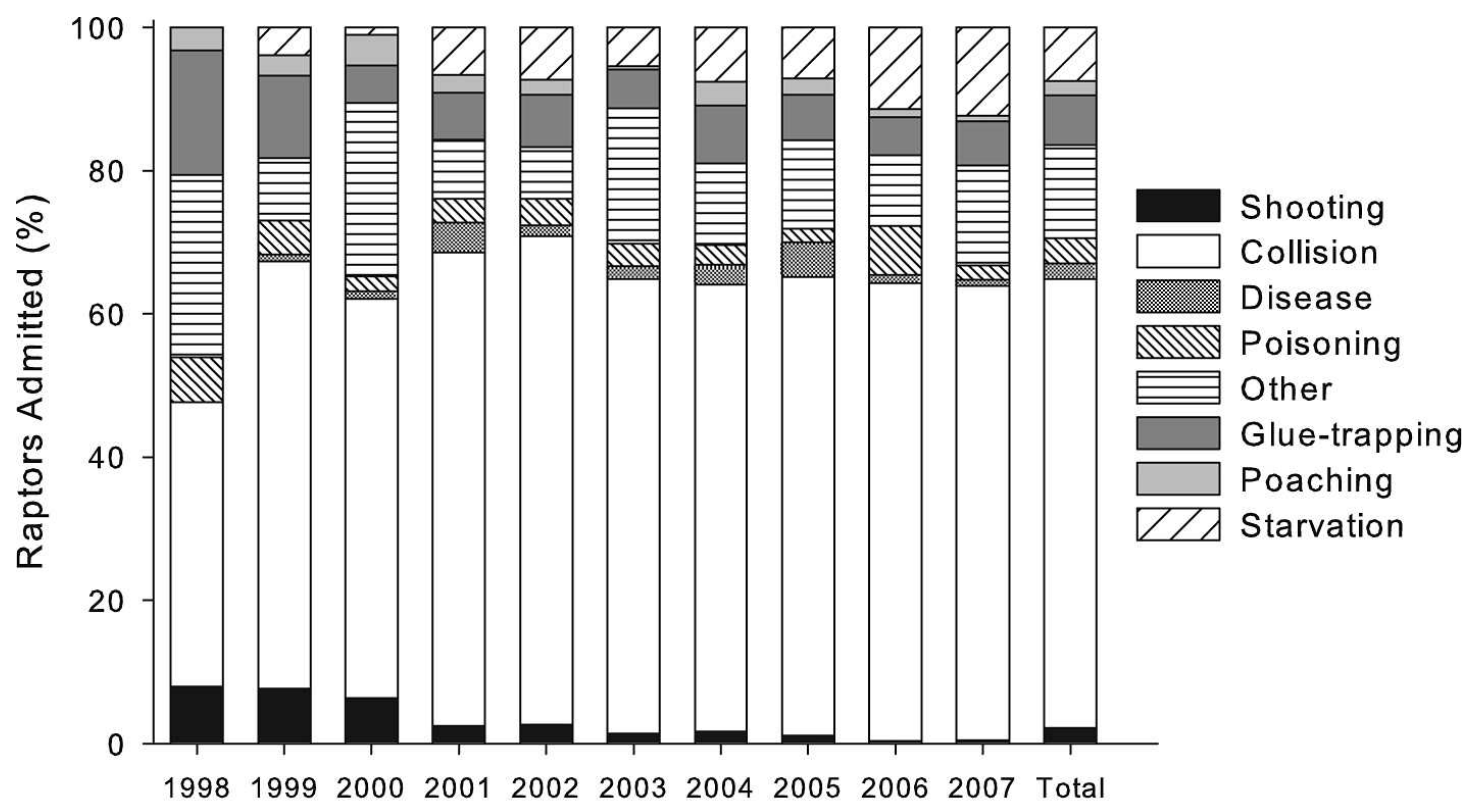

Year

Figure 3. Annual variation in causes of admission of raptors to Tenerife (Canary Islands) Wildlife Rehabilitation Center "La Tahonilla" during 1998-2007.

$\mathrm{df}=9$; Fig. 3), but poisoning, glue-trapping, poaching, and other causes did not (all Gvalues $<20.75$, all $P>0.14$, df $=9$ ). An increase in the admission rate due to collisions was observed during the study period (Fig. 3).

Recovery Rate. A total of 335 (12.8\% of total admissions) individuals were already dead when admitted to the WRC. Lethality varied among causes of admission $(G=32.32$; $\mathrm{df}=6, P<0.001)$. For example, a higher proportion of birds affected by glue-trapping were successfully released than birds admitted for all other reasons (Fig. 4). A total of 1010 birds (44.4\% of admitted birds excluding those that were dead when reported to the WRC) were successfully released to the wild following rehabilitation, and the rest were considered untreatable after diagnosis (Table 3) and were either euthanized or maintained in captivity for education, conservation, or scientific purposes.

\section{Discussion}

Although radiotracking using conventional radiotransmitters or PTTs provides more precise mortality data (Kenward 1993), the analysis of carcasses or injured individuals admitted to rehabilitation centers has been commonly used as an index to causes of mortality (Work and Hale 1996, Newton et al. 1997 and 1999, Wendell et al. 2002, Martínez et al. 2006, Kelly and Bland 2006, González et al. 2007, Margalida et al. 2008) because it is inexpensive, efficient, provides large sample sizes, and covers large geographical areas. However, biases from such data can affect results in different ways. Data collected over a long period may suffer from observer bias or observer drift, or be biased because sick or injured birds are more likely to be brought to the center than carcasses. This may explain the fact that no birds were admitted to the WRC in Tenerife presenting symptoms of electrocutions (e.g., electric burns), as these victims often die immediately (Wendell et al. 2002). Furthermore, the number of deaths and injuries related to collisions with human-made structures may be overestimated, whereas other causes of injury such as poisoning may be underestimated because birds die in remote places (Cooper 2004, Margalida et al. 2008). Gun-shot raptors are usually thought to be underestimated in retrospective analyses of injured or dead birds, because shooting victims are difficult to find and are often hidden or destroyed by hunters (González et al. 2007).

Feeding habits and body shape in raptors may promote differences in the incidence of different 


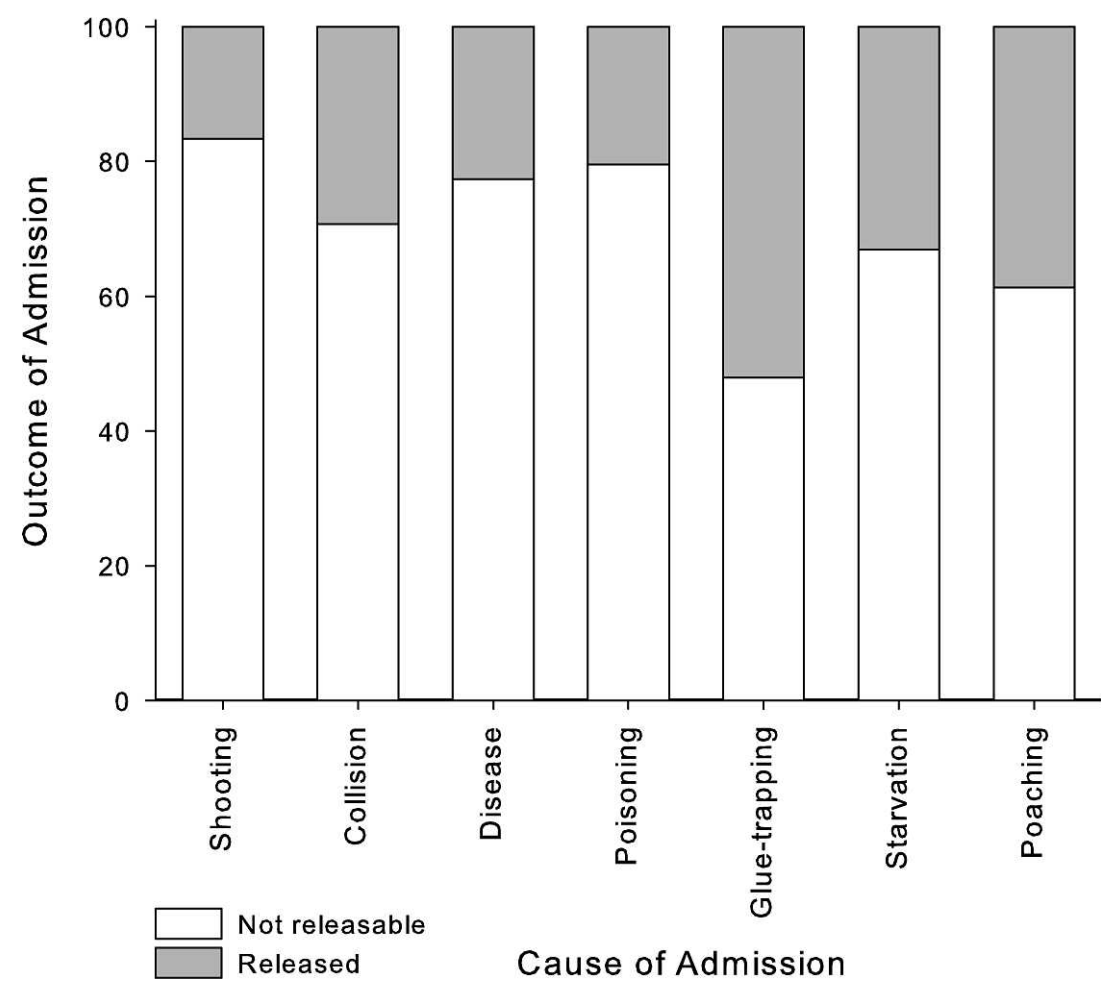

Figure 4. Outcome of admission (\%) relative to cause of admission for raptors at the Wildlife Rehabilitation Center "La Tahonilla" (Tenerife, Canary Islands) during 1998-2007.

mortality factors (Kerlinger and Ross 1988, Massemin and Handrich 1997, Wendell et al. 2002). Thus, scavengers may be more susceptible to poisoning (Miller et al. 2002, Hernández and Margalida 2008 and 2009), large soaring birds are more likely to be injured by electrocution on power lines (Janss 2000) and owl species may be more affected by vehicle collisions (Keran 1981, Lodé 2000, Erritzøe et al. 2003).

In many studies, trauma and injuries caused by different collisions, especially with human-made structures, have been reported as important sources of nonnatural mortality in raptors (Keran 1981, Newton 1986, Wendell et al. 2002, Erritzøe et al. 2003, Krone et al. 2003, Kelly and Bland 2006, Harris and Sleeman 2007). Our results suggest that collisions (including vehicle collisions, collisions with high-voltage transmission towers, etc.) are an important mortality cause on Tenerife. The number of collisions (together with the number of total admissions) may be increasing in a landscape subject to increasing development. Roads, traffic, construction, transmission towers, and other urban land- scape features have all been rapidly increasing in the Canary Islands during the last four decades (Beltrán 2001). Similar threats have been reported for other raptorial birds in continental areas (Fajardo 2001, Margalida et al. 2008).

Glue-traps are a type of nonlethal or restraining trap commonly used for domestic rodent control in the Canary Islands (B. Rodríguez unpubl. data). We documented a relatively high number of birds admitted to the WRC with plumage damage due to contact with the adhesive used in these traps. In these cases, it seems that raptors contacted the adhesive material when they attempted to capture rodents or reptiles that were already caught in these traps. This admission category yielded the highest percentage of birds released to the wild (see Fig. 4), likely because the majority of such birds presented only relatively minor plumage damage, with no broken bones or severe injuries when admitted (WRC pers. comm.). Also, birds injured by glue-traps were often detected, because the traps are monitored by people. However, these traps have only rarely been reported in the literature as a cause of mortality or 
admission to rehabilitation centers (Harden 2002, Burton and Doblar 2004). For this reason, regulation of these popular products and educational campaigns, focusing on their pernicious effects, should be developed in the Canary Islands to reduce the number of raptor injuries.

Direct human persecution is an important factor in population trends of many raptor species (Elliot and Avery 1991, Real et al. 2001, Martínez et al. 2006, González et al. 2007, Margalida et al. 2008). Although raptors are legally protected, shooting still affects large birds in Europe and the Canary Islands, even outside the hunting season (Fig. 2). This cause of admission was not as important as other factors such as collision, and it also decreased over the study period. However, especially for some rare or threatened insular species (not necessarily only raptors), shooting must be eliminated to ensure the long-term viability of vulnerable populations. Other raptors such as the Barbary Falcon have undergone an important recovery in Tenerife during the last two decades, and conflicts with hunters and especially with pigeon fanciers have increased (Rodríguez et al. 2007). Awareness campaigns involving hunters and pigeon-fanciers' associations could minimize human persecution of this species.

According to our data, poisoning is not an important cause of nonnatural mortality in birds on Tenerife, at least currently. However in the 1950s, DDT was heavily used in the Canary Islands to fight eruptions of desert locusts (Schistocerca gregaria) from Africa (Del Cañizo 1954). The use of this pesticide, together with direct human persecution, likely caused the extirpation of the Red Kite and the retreat of the Egyptian Vulture to the eastern islands (Palacios 2004). Recent analyses of tissues from Egyptian Vultures of Fuerteventura and from Eurasian Kestrels of Tenerife have revealed that they still contain the highest concentrations of DDT for these raptor species in Spain (Mateo et al. 2000, Gomara et al. 2004), although they are now below the levels considered toxic. Furthermore, some people living in the Canary Islands have a high DDT/ DDE ratio, due to chronic exposure to DDT (Zumbado et al. 2005). This suggests that contaminant studies should be performed to evaluate the effects of current and past use of pesticides on the Canarian wildlife.

Finally, analyses of the type presented here can provide insight into population trends and the conservation status of threatened species (González et al. 2007, Margalida et al. 2008). Monitoring causes of mortality in wild raptor populations is difficult, so analyses of injured or dead birds can provide indirect data for raising social awareness and for monitoring or formulating hypotheses about population trends, and large-scale landscape changes (Fajardo 2001, Wendell et al. 2002). Wildlife rehabilitation centers can also reduce human-related mortality in raptor populations and provide information on the biology of different species (Wendell et al. 2002, Cooper 2004, Margalida et al. 2008). The proportion of injured raptors that are subsequently released to the wild varied among species and sites. However, detailed studies on the life expectancy and fate of these birds, based on radiotelemetry and band-recovery data, are urgently needed to ameliorate the efficiency of the rehabilitation process, especially in the Canaries, where knowledge on such aspects is minimal (Fajardo et al. 2000, Kelly and Bland 2006, present study). Furthermore, precise clinical and contaminant analyses are necessary to assess the population health of raptors (Gangoso et al. 2009). For this, complete necropsies may help detect adverse effects of contaminants and poisons on body condition both in the wild and in rehabilitated individuals (Lemus et al. 2008, Bataglia et al. 2005, Gangoso et al. 2009). Finally, more funding is needed to improve the functioning of WRC and also to perform parallel field studies on causes of raptor mortality in the Canary Islands.

\section{ACKNOWLEDGMENTS}

Special thanks to all the anonymous people who kindly helped rescue the birds, and to the staff of the Wildlife Rehabilitation Center "La Tahonilla" (Cabildo Insular de Tenerife). Thanks to J. Olsen, S. Trost, J.J. Negro, L. Tapia, A. Margalida, F. Sergio, and an anonymous referee for comments on the early drafts of this manuscript.

\section{Literature Cited}

Bataglia, A., S. Ghidini, G. Campanini, and R. SAPggiari. 2005. Heavy metal contamination in Little Owl (Athene noctua) and Common Buzzard (Buteo buteo) from northern Italy. Ecotoxicol. Environ. Saf. 60:61-66.

Beltrán, W. 2001. El ámbito insular en la ordenación del territorio. Pages 351-355 in J.M. Fernández-Palacios, and J.L. Rodríguez [EDS.], Naturaleza de las Islas Canarias, ecología y conservación. Turquesa Ediciones, S/C de Tenerife, Spain.

Bevanger, K. 1998. Biological and conservation aspects of bird mortality caused by electric power lines: a review. Biol. Conserv. 86:67-76.

Burton, D.L. AND K.A. Doblar. 2004. Morbidity and mortality of urban wildlife in the midwestern United States. Pages 171-181 in W.W. Shaw, L.K. Harris, and L. Van- 
druff [EDS.], Proceedings of the Fourth International Symposium on Urban Wildlife Conservation, Tucson, AZ U.S.A.

Cabildo Insular de Tenerife. 2009. Plan insular de ordenación de Tenerife. http://www.tenerife.es/PIOT/index. asp (last accessed 11 December 2009).

Carrillo, J. and G. Delgado. 1991. Threats to and conservationist aspects of birds of prey in the Canary Islands. Birds of Prey Bull. 4:25-32.

CoOper, J.E. 2004. Information from dead and dying birds. Pages 179-209 in W.J. Sutherland, I. Newton, and R.E. Green [EDS.], Bird ecology and conservation. Oxford University Press, Oxford, U.K.

Del CAÑizo, J. 1954. Invasión de la langosta peregrina en Canarias (Octubre de 1954). Bol. Pat. Veg. Entom. Agr. 20:409-431.

Donázar, J.A., L. Gangoso, M.G. Forero, and J. Juste. 2005. Presence, richness and extinction of bird of prey in the Mediterranean and Macaronesian islands. J. Biogeogr. 32:1701-1713

- C.-J. Palacios, L. Gangoso, O. Ceballos, M.J. GonZÁleZ, AND F. HiRAldo. 2002. Conservation status and limiting factors in the endangered population of Egyptian Vulture (Neophron percnopterus) in the Canary Islands. Biol. Conserv. 107:89-97.

Duncan, R.P. AND T.M. BlackBuRn. 2007. Causes of extinction in island birds. Anim. Conserv. 10:149-150.

Elliot, G.D. AND M.I. AvERy. 1991. A review of reports of buzzard persecution 1975-89. Bird Study 38:52-56.

ERritzøe, J., T.D. MAZgajSki, AND L. RejT. 2003. Bird casualties on European roads - a review. Acta Ornithol. 38:77-93.

FAJARDO, I. 2001. Monitoring non-natural mortality in the Barn Owl (Tyto alba) as an indicator of land use and social awareness in Spain. Biol. Conserv. 97:143-149.

-, G. BABILONI, AND Y. MiRAndA. 2000. Rehabilitated and wild Barn Owls (Tyto alba): dispersal, life expectancy and mortality in Spain. Biol. Conserv. 94:287295.

Gomara, B., L. Ramos, L. Gangoso, J.A. Donázar, And M.J. GONZÁLEZ. 2004. Levels of polychlorinated biphenyls and organochlorine pesticides in serum samples of Egyptian Vulture (Neophron percnopterus) from Spain. Chemosphere 55:577-583.

Gangoso, L., P. Álvarez-Lloret, A.A.B. RodríguezNavarro, R. Mateo, F. Hiraldo, and J.A. Donázar. 2009. Long-term effects of lead poisoning on bone mineralization in bones exposed to ammunition sources. Environ. Pollut. 157:569-574.

González, L.M., A. Margalida, S. Mañosa, R. Sánchez, J. Oria, J.L. Molina, J. Caldera, A. Aranda, and L. Prada. 2007. Causes and spatio-temporal variations of non-natural mortality in the vulnerable Spanish Imperial Eagle Aquila adalberti during a recovery period. Oryx 41: 495-502.

HaRden, J. 2002. An overview of anthropogenic causes of avian mortality. J. Wildl. Rehab. 25:4-11.
Harris, M.C. AND J.M. SleEman. 2007. Morbidity and mortality of Bald Eagles (Haliaeetus leucocephalus) and Peregrine Falcons (Falco peregrinus) admitted to the wildlife center of Virginia, 1993-2003. J. Zoo Wildl. Med. 38:62-66.

Hernández, M. And A. Margalida. 2008. Pesticide abuse in Europe: effects of the Cinereus Vulture (Aegypius monachus) population in Spain. Ecotoxicology 17:264-272.

— AND —. 2009. Poison-related mortality effects in the endangered Egyptian Vulture (Neophron percnopterus) population in Spain: conservation measures. Eur. J. Wildl. Res. 55:415-423.

JANSS, G.F.E. 2000. Avian mortality from power lines: a morphologic approach species-specific mortality. Biol. Conserv. 95:353-359.

Kelly, A. AND M. Bland. 2006. Admissions, diagnoses, and outcomes for European Sparrowhawks (Accipiter nisus) brought to a wildlife rehabilitation center in England. J. Rap. Res. 40:231-235.

KENWARD, R.E. 1993. Modelling raptor populations: to ring or to radio-tag? Pages 157-167 in J.D. Lebretonand and P.M. North [EDS.], Marked individuals in the study of bird populations. Birkhäuser Verlag, Basel, Switzerland.

KerAN, D. 1981. The incidence of man-caused and natural mortalities to raptors. Raptor Res. 15:108-112.

Kerlinger, P. AND M. Ross. 1988. Causes of mortality, fat conditions and weights of wintering Snowy Owls. J. Field Ornithol. 59:7-12.

Krone, O., T. Langgemach, P. Sömmer, and N. Kenntner. 2003. Causes of mortality in White-tailed Sea Eagle from Germany. Pages 211-218 in B. Helander, M. Marquis, and W. Bowerman [EDs.], Sea Eagle 2000: proceedings from an international conference at Björkö, Sweden. Swedish Society for Nature Conservation/SNF, Stockholm, Sweden.

Lemus, J.Á., G. Blanco, J. Grande, B. Arroyo, M. GarcíaMontijano, And F. Martínez. 2008. Antibiotics threaten wildlife: circulating quinolone residues and disease in avian scavengers. PLoS ONE 3(1): e1444 doi:10.1371/ journal.pone.0001444.

LODÉ, T. 2000. Effect of a motorway on mortality and isolation of wildlife populations. Ambio 29:165-168.

López, T.J., M.E. Álvarez, M.A. Lage, And J. Simal. 2001. Aliphatic hydrocarbons in birds of prey from Galicia (NW Spain). Ecotoxicol. Eviron. Saf. 50:44-47.

LORENZO, J.A. [ED.]. 2007. Atlas de las aves nidificantes en el archipiélago canario (1997-2003). Dirección General de Conservación de la Naturaleza-Sociedad Española de Ornitología, Madrid, Spain.

Madroño, A., C. González, and J.C. Atienza. [Eds.]. 2004. Libro Rojo de las Aves de España. Dirección General para la Biodiversidad-SEO/BirdLife, Madrid, Spain.

Margalida, A., R. Heredia, M. Razin, and M. Hernández. 2008. Sources of variation in mortality of the Bearded Vulture Gypaetus barbatus in Europe. Bird Conserv. Int. 18:1-10. 
Martín, A. AND J.A. Lorenzo. 2001. Aves del archipiélago canario. Lemus Editor, La Laguna, Spain.

Martínez, J.A., J.E. Martínez, S. MaÑosa, I. Zuberogoitia, AND J.F. CALvo. 2006. How to manage human-induced mortality in the Eagle Owl Bubo bubo. Bird Conserv. Int. 16:265-278.

MASSEMIN, S. AND Y. HANDRICH. 1997. Higher winter mortality of the Barn Owl compared to the Long-eared Owl and Tawny Owl: influence of lipid reserves and insulation? Condor 99:969-971.

Mateo, R.J., J. Carrillo, and R. Guitart. 2000. P, p'-DDE residues in eggs of European Kestrel Falco tinnunculus from Tenerife, Canary Islands, Spain. Bull. Environ. Contam. Toxicol. 65:780-785.

Miller, M.J.R., M.E. Wayland, ANd G.R. Bortolotti. 2002. Lead exposure and poisoning in diurnal raptors: a global perspective. Pages 224-245 in R. Yosef, M.L. Miller, and D. Pepler [EDs.], Raptors in the new millennium. International Birding and Research Center in Eilat, Israel.

Morales, G. And R. Pérez. 2000. Gran atlas Temático de Canarias. Editorial Interinsular Canaria, Santa Cruz de Tenerife, Spain.

National Statistic Institute of Spain. 2009. Population data. http://www.ine.es/ (last accessed 11 December 2009).

Newton, I. 1986. The sparrowhawk. T. and A.D. Poyser, Staffordshire, U.K..

- I. Wyllie, And L. Dale. 1997. Mortality causes in British Barn Owls (Tyto alba), based on 1,101 carcasses examined during 1963-96. Pages 299-307 in J.R. Duncan, D.H. Johnson, and T.H. Nicholls [EDs.], Biology and conservation of owls of the northern hemisphere. Second International Symposium, Manitoba, Canada.
1999. Trends in the numbers and mortality patterns of sparrowhawks (Accipiter nisus) and kestrel (Falco tinnunculus) in Britain, as revealed by carcass analyses. J. Zool. Lond. 248:139-147.

PAIN, D.J. AND C. AMIARD-TRIQUET. 1993. Lead poisoning of raptors in France and elsewhere. Ecotoxicol. Environ. Saf. 25:183-192.

Palacios, C.-J. 2004. Current status and distribution of birds of prey in the Canary Islands. Bird Conserv. Int. 14:203-213.

Real, J., J.M. Grande, S. Mañosa, and J.A. Sánchez-Zapata. 2001. Causes of death in different areas for Bonelli's Eagle Hieraaetus fasciatus in Spain. Bird Study 48:221228.

Rodríguez, A., F. Siverio, R. Barone, B. Rodríguez, And J.J. Negro. 2009. An overlooked cost for the velvety plumage of owls: entanglement in adhesive vegetation. Wilson J. Ornithol. 121:439-441.

Rodríguez, B., M. Siverio, A. Rodríguez, AND F. Siverio. 2007. Density, habitat selection and breeding success of an insular population of Barbary Falcon Falco peregrinus pelegrinoides. Ardea 95:213-223.

Wendell, M.D., J.M. Sleeman, And G. Kratz. 2002. Retrospective study of morbidity and mortality of raptors admitted to Colorado State University Veterinary Teaching Hospital during 1995-96. J. Wildl. Dis. 38:101-106.

WORK, T.M. AND J. HALE. 1996. Causes of owl mortality in Hawaii, 1992 to 1994. J. Wildl. Dis. 32:266-273.

Zumbado, M., M. Goethals, E.E. Álvarez-León, O.P. Lurardo, F. Cabrera, L. Serra-majem, and L. DomínguezBOADA. 2005. Inadvertent exposure to organochlorine pesticides DDT and derivates in people from the Canary Islands (Spain). Sci. Total Environ. 339:49-62.

Received 25 May 2009; accepted 25 October 2009 Associate Editor: Fabrizio Sergio 